\title{
COMPLEMENTARITY BETWEEN PUBLIC AND PRIVATE INVESTMENT IN INDIA
}

\author{
B.K. PRADHAN, D.K. RATHA and Atul SARMA* \\ Indian Statistical Institute, New Delhi-110016, India
}

Received May 1988, final version received November 1988

In this paper, we examine the question of complementarity between public and private investment in India under different modes of allocation and financing of public investment. We use an 18 sector computable general equilibrium model where money plays a non-neutral role. We find that public investment crowds out private investment; but in terms of its effect on total investment and growth and distribution of income, the economy is better off with increased public investment. That raises the question: Is crowding out all that undesirable?

\section{Introduction}

The relation between public and private investment in India has been a topic of recurrent debates. On the one hand, it is argued that by undertaking lumpy and risky investment, the public sector complements private investment by way of creating necessary infrastructure and providing critical inputs. On the other hand, public investment is accused of crowding out private investment. Thus, there are two aspects to this debate: (i) 'complementarity' and (ii) 'crowding out'. Most of the existing literature [e.g., Sundararajan and Thakur (1980), Krishnamurty (1985)] have studied these aspects without any reference to the modes of financing and the manner of allocation of the public sector investment. ${ }^{1}$ Besides, these studies are restrictive in scope in that they have examined only the growth implications of crowding out and complementarity effects, but ignored their implications

\footnotetext{
*The authors are immensely grateful to two anonymous referees for their detailed comments and constructive suggestions.

${ }^{1}$ Sundararajan and Thakur (1980) found that an increase in public investment crowds out private investment and hampers growth of national income. Krishnamurthy (1985), on the other hand, found that increased public investment results in crowding out of private investment, but leads to higher growth. See also Chetty, Pradhan and Sarma (1987) and Pradhan (1987) for a macro-theoretic treatment of different modes of financing of public investment on growth, income and prices in the context of a developing economy.
} 
on prices and income distribution. In India, a major reason why public investment was assigned such importance as it has is because the policy makers wanted to exercise control over prices and output in the economy to further the nations' equity goals [Government of India (1956, pp. 9-10), World Bank (1979, p. 10)]. It is important, therefore, to study all these aspects while examining the relation between public and private investment.

In this paper, we will examine the following questions:

(1) If the public sector investment is stepped up by a certain percentage, what would be the impact on private and total investment in the economy?

(2) What is the impact of increased public investment on prices, income generation and distribution?

(3) How does the impact vary as the mode of allocation and financing of public investment changes?

The examination of these questions necessitates a precise definition of 'complementarity' and 'crowding out'. Public investment is 'complementary' to private investment if an initial increase in public investment leads to an increase in the total investment in the economy. Public investment crowds out' private investment, if the latter decreases as a result of an increase in the former. Given the exogenous nature of public investment, any increase in total investment (as a result of an initial reallocation of investment from the private to the public sector) is essentially due to an increase in private investment alone. So our definition, similar to what is implicitly used in the literature, implies complementarity between public and private investment [see Sundararajan and Thakur $(1980$, p. 2)]. It follows that complementarity and crowding out may coexist and are inversely related to one another. ${ }^{2}$

For the types of questions the paper is addressed to, we require a model with the following features:

- Public and private sector should be clearly distinguished. Within the private sector, there should be at least two classes in terms of income sources such as earners of wage and non-wage incomes for studying equity of public investment decisions.

- Generation and distribution of income should be linked to production processes in the economy for evaluating growth and distribution effects.

\footnotetext{
${ }^{2}$ To give an example, let us say initially public and private investment are Rs. 1,000 crores each. Now public investment is stepped up by Rs. 100 crores. Since this amount of real resources has to come from the private sector, private investment ought to become Rs. 900 crores, if there were no complementarity effects. Suppose that at the new equilibrium, private investment becomes Rs. 940 crores. Total investment will then be Rs. 2,040 crores, 40 crores higher than earlier. We will say that the complementarity effect is Rs. 40 crores, whereas the crowding out effect is Rs. 60 crores and not 100 crores.
} 
- Prices should be endogenously determined for capturing price effects.

- There should be more than one commodity group for studying the impact of different investment allocation rules.

- There should be flexibility for capturing differential impact of alternative modes of financing public investment.

A computable general equilibrium (CGE) model set up in a non-Walrasian framework with financial markets can incorporate all the above features. Therefore, a model of this type is eminently suitable for our purpose.

The plan of the paper is as follows: Section 2 describes in brief a CGE model of India. Section 3 takes up the question of complementarity between public and private investment under different modes of allocation and financing of public investment. Section 4 contains a few concluding remarks.

\section{The model in brief}

The economy in our model ${ }^{3}$ is represented by 18 sectors -17 commodity sectors and one financial sector - and three classes - government, business and household. The household sector comprises five income groups each in urban and rural areas. These income groups are broadly classified as earners of wage income and non-wage income. The business sector represents private producers. Commodities are broadly grouped under three heads - final goods, intermediate goods and investment goods. There are six final goods (foodgrains, consumer non-durables non-textiles, cotton textiles, synthetic textiles, consumer durables and services), nine intermediate goods (iron and steel ferro-alloys, iron and steel casting and forging, coal and lignite, crude petroleum and natural gas, electricity, fertilizer and pesticides, cement, industrial raw materials and other basic and intermediate goods) and two investment goods (construction and plant and equipment).

For final goods (except foodgrains and textiles), demand equations are estimated as functions of prices and income using time series data for the period 1960-61 to 1980-81. For foodgrains and textiles, we have calibrated income groupwise demand functions. ${ }^{4}$ For the intermediate goods, demands are derived by using fixed input-output coefficients. Supply of final goods are price-responsive and estimated econometrically. Bank credit enters as a variable in the supply functions of final goods. Supplies of intermediate

\footnotetext{
${ }^{3}$ For a detailed discussion of the model, see Chetty and Ratha (1987), Ratha (1987). Here we highlight only those aspects of the model which are directly relevant to the present exercise.

${ }^{4}$ Each of the income group specific demand function is of the form $\log (D)=a-b \log (p)+$ $c \log (Y)$ where $D$ is demand, $b$ is price elasticity, $p$ is price, $c$ is income elasticity and $Y$ is income of a particular income group. Using actual data on $D, p$ and $Y$ for one year (1980-81) and taking $b$ and $c$ from Murty and Radhakrishna (1981), we have worked out the intercept term $a$ We call the demand function thus obtained as calibrated [see Shoven and Whalley (1984, p. 1018)].
} 
goods are exogenously given in the first period, but endogenised in the second period by using incremental capital-output ratios and some investment allocation rules.

In the absence of a capital coefficients matrix, the demand for and the supply of capital goods (comprising machinery and equipment and construction) are empirically estimated. The equations are given in Appendix A.

National income is derived as the sum of value-added in all the commodity sectors. The generation of value added in the commodity sectors and its distribution among the five income groups each in urban and rural areas are computed using a matrix of value added coefficients.

Total investment is obtained as the sum of the value of construction and that of machinery and equipment. Public investment is assumed to be exogenously given in real terms. Private investment is obtained by subtracting public investment from the total investment.

The financial sector comprises two assets - money and bank credit. Money is created by the central bank to meet the deficit in the government budget. We assume that whatever money is printed is readily demanded by the household sector for transaction purposes. Supply of bank credit in an administered interest rate regime depends upon the banks' currency holdings subject to statutory conditions such as cash-reserve ratio. Banks' currency holdings in turn depend upon the volume of new currency and saving habits of the people. We therefore use the following econometrically estimated equation: 5

$$
S_{\text {CREDIT }}=-210.13+0.84 F I N S A V+1.34 D E F I C I T,
$$

where

FINSAV = savings of the household on financial assets, and

$D E F I C I T=$ government budget deficit.

Bank credit is demanded by the government and the business sector. The government's demand for credit is obtained as a fixed fraction of its investment expenditure. The private demand for credit, $C R$, is obtained as

\footnotetext{
'All the coeficients of this equation are significant: $\bar{R}^{\gamma}=0.95, D . W=2.25, D . F .=20$. Interest rates are administered in India. Since there is a complex rate structure, it is difficult to choose one particular rate as a representative one. Moreover, although there are occasional jumps in the administered interest rates, the variability from year to year is low [for example, the scheduled commercial bank demand loan rate jumped from 8.5-12.0 percent in 1970-71 to 15.5 percent in 1975-76 and remained constant thereafter till 1980-81]. As a result, econometrically estimated equations using even weighted average of interest rates as one of the independent variables were not found to be meaningful. Therefore, the interest rate has not been used in the supply and demand functions for credit. In the supply functions of final goods, we had to use the volume of credit instead of the interest rate.
} 


$$
C R=P R I-P H Y S A V-B O N D S,
$$

where PRI is private investment in current prices, PHYSAV is household saving in physical assets and BONDS are household sector's subscription to shares and debentures issued by the business sector.

The government finances its expenditures through taxes, market borrowing and surplus of public enterprises. Its deficit is met through money creation. The busincss sector balances its budget by borrowing from commercial banks - its budget constraint is given by eq. (2). For the household sector, savings are obtained as a residual after deducting consumption expenditure from its disposable income. The household savings are split between PHYSAV and FINSAV in the ratio $\left(1-s_{\mathrm{f}}\right): s_{\mathrm{f}}$ where $s_{\mathrm{f}}$ is given. FINSAV includes, among other things, currency and BONDS. Since each class satisfies its budget constraint, Walras' law is verified.

It is assumed that the private sector invests in final goods and a part of investment goods, while public investment is allocated among the remaining part of investment goods and the intermediate goods. ${ }^{6}$ It is also assumed that there is a one-period lag between investment and output of the public sector, while private sector production is instantaneous. ${ }^{7}$ Since supply of goods in the private sector is price-responsive, private investment (and also bank credit) is implicitly allocated according to market signals. Public investment is allocated according to the pattern of excess demand - this rule is similar to the one implicit in the consistency framework adopted in Indian plans [see, e.g., Government of India (1981)].

The prices of goods produced in the private sector are obtained when demand equals supply in each market. It may be noted here that these prices may be different from those obtained by adding average material cost to the exogenously given value added coefficients. The difference, if any, is adjusted against the exogenous component of government expenditure. For goods produced in the public sector, prices are administered according to cost plus a given mark-up rule.

The economy is said to be in equilibrium when excess demand is zero in the final and investment goods sectors and demand does not exceed supply in the intermediate goods sectors as well as the financial market. The excess demand of intermediate goods, if any, is met through imports. We assume export earnings to be given so that the trade deficit is financed either by

\footnotetext{
${ }^{6}$ The basis of this assumption is that under the industrial policy formulated and pursued in India, most intermediate goods and a large part of the capital goods are earmarked for public sector production. See Government of India (1986, pp. 9-11).

${ }^{7}$ This lag structure is simplistic. Keeping in view the computational complexity, it is built in just to indicate the greater roundaboutness of production and the tardiness in investment decision making and implementation in the public sector.
} 
Table 1

Computed values for $1980-81$.

\begin{tabular}{|c|c|c|c|}
\hline Variable & Unit & Computed $v$ & Actual value \\
\hline 1. General price index & $\begin{array}{l}\text { Index with base } \\
1970-71=100.0\end{array}$ & 242.53 & 243.97 \\
\hline $\begin{array}{l}\text { 2. GDP at factor cost in } \\
\text { current prices }\end{array}$ & Rs $(000$ crores & $112,447.1$ & $114,021.0$ \\
\hline $\begin{array}{l}\text { 3. Disposable income of the household } \\
\text { in current prices }\end{array}$ & Rs '000 crores & $99,690.6$ & $105,104.0$ \\
\hline 4. Wage income in current prices & Rs 000 crores & $50,293.9$ & $43,110.6$ \\
\hline 5. Household savings in current prices & Rs '000 crores & $19,260.6$ & $17,155.0$ \\
\hline 6. Private investment in current prices & Rs 000 crores & $15,500.7$ & $17,492.0$ \\
\hline 7. Public intvestment in current prices & Rs 000 crores & $13,868.1$ & $13,926.0$ \\
\hline $\begin{array}{l}\text { 8. Government expenditure in } \\
\text { current prices }\end{array}$ & Rs 000 crores & $36,529.8$ & $36,845.0$ \\
\hline $\begin{array}{l}\text { 9. Government revenue in } \\
\text { current prices }\end{array}$ & Rs 000 crores & $33,818.5$ & $33,394.0$ \\
\hline 10. Government budget deficit & Rs '000 crores & $2,711.3$ & $3,451.0$ \\
\hline 11. Supply of bank credit & Rs '000 crores & $12,543.9$ & $10,236.0$ \\
\hline 12. Imports & Rs '000 crores & $8,299.3$ & $9,759.6$ \\
\hline 13. Gini ratio (rural) & Rs ' 000 crores & 0.2972 & - \\
\hline 14. Gini ratio (urban) & Rs ' 000 crores & 0.2756 & - \\
\hline
\end{tabular}

drawing from foreign exchange reserves or by net capital inflow from abroad or both. ${ }^{8}$ The government always gets its required amount of bank credit by using instruments such as $S L R$ (statutory liquidity ratio). If demand for financial credit exceeds its supply, credit to the private sector is rationed.

The model is solved using the fixed-point routine developed by Saigal (1979). In the base simulation, the model is solved for two periods, 1980-81 and 1981-82, using observed data on exogenous variables and various coefficients and rates. The computed values of macro-variables in period 1 (i.e., 1980-81) are compared with their actual values in table 1 to check the explanatory power of the model. It is observed that the simulation is reasonably close to reality.

Having described the model, it will be useful to indicate the broad directions of linkages between public investment and the endogenous variables of the model. When public investment increases, the initial crowding out of the private investment will lead to a lower demand for working capital (credit). That will shift the supply curve of final goods to the left and the value added from these sectors will decrease. On the other hand, value added in the public sector will increase as a result of increased public investment. The relative strength of these two opposing effects will determine the net

\footnotetext{
${ }^{8}$ This assumption is reasonable while simulating small changes in public investment, but one has to carefully account for the trade deficit while comparing the other marco-variables between simulations.
} 
change in national income and wage income and hence the demand for commodities. Again, supply and demand vectors will be affected by the mode of financing and allocation of public investment. The total impact on prices as well as macro-variables (including private investment) will eventually depend on how the supply and demand curves move relative to each other.

It is apparent that the behaviour of various economic variables in response to an initial increase in public investment is a priori unpredictable. Therefore, our questions necessitate empirical verification.

\section{Complementarity between public and private investment}

In our simulations, we consider a 10 percent increase in public investment financed in the following ways:

Case I through money creation;

Case II by increasing direct taxes on the highest income group;

Case III by increasing the mark-up uniformly on all administered prices, except industrial raw materials;

Case IV by market borrowing.

We consider six schemes - three investment allocation rules, each one with and without wage indexation - such as:

Scheme 1 public investment allocated in proportion to the excess demand in each intermediate goods sector;

Scheme 2 Scheme 1 with 25 percent wage indexation;

Scheme 3 public investment allocated according to excess demand weighted by value-added coefficient in each sector; ${ }^{9}$

Scheme 4 Scheme 3 with 25 percent wage indexation;

Scheme 5 public investment allocated according to excess demand weighted by wage coefficient in each sector;

Scheme 6 Scheme 5 with 25 percent wage indexation.

Wages are indexed to the food prices, the indexation factor being 0.25 (i.e., for every 1 percent increase in food prices, the wage rate is increased by 0.25 percent). ${ }^{10}$

\footnotetext{
${ }^{9} T$ That is, if $v_{i}=$ value added coefficient, $E D_{i}=$ excess demand and $P B I=$ public investment, the ith intermediate good receives $\left(v_{i} E D_{i} / \sum v_{i} E D_{i}\right) P B I$ amount of public investment.

${ }^{10} \mathrm{It}$ is interesting to note that our model does not converge to equilibrium when the indexation factor is more than 25 percent. Jha and Mundle (1987) also estimated the indexation factor in India to be close to 25 percent, although indexation in their model was with respect to the wholesale price index. Thus the schemes $(2,4$ and 6) with wage-indexation may be regarded as more realistic.
} 
As already mentioned, the allocation rule under Schemes 1 and 2 is similar to the one implicit in the Indian plan models. Schemes 3 and 4 can be regarded as growth-oriented, whereas Schemes 5 and 6 as equity-oriented investment policies. ${ }^{11}$

In all the simulations (except Case IV which will be discussed later), public investment is increased by 10 percent over the base level both in periods 1 and 2 (10 percent increase in public investment is equal to about 4.4 percent of the total investment in 1980-81). The results are shown in tables 2, 3 and 4. In the tables, the percentage changes in period 1 (period 2) are computed with respect to period 1 (period 2) of the base simulation. Since schemes with wage indexation are more realistic, we will mainly discuss the results of Schemes 2, 4 and 6. We will refer to the other schemes wherever necessary.

Before looking into the results, it will be useful to clarify that in period 1, the results are identical across the comparable schemes. This is because of the one-year lag between investment and accrual of output which causes the differential impact of investment allocation rules only in the second period.

Examining Cases I, II and III, it can be observed:

(1) A comparison of the results relating to schemes with and without wage indexation reveals that the complementarity effect - as given by the rate of growth of gross domestic capital formation (GDCF) - is higher, while the crowding out effect - as indicated by the rate of decline in the private investment - is lower in both periods under the schemes with wageindexation. The growth of national income is also higher under these schemes. This is because every increase in public investment is accompanied by a price effect and also an income effect. When wages are protected, the income effect becomes stronger resulting in higher investment, growth and prices. Under these schemes, wage income increases faster than the disposable income implying an improvement in the share of wages in disposable

\footnotetext{
${ }^{11}$ If the goal is to allocate public investment to maximize the increase in wages (value added), sectoral allocations should be proportional to the wage (value added) coefficient divided by $I C O R$. Under Case II, for example, we found the following results:
}

\begin{tabular}{lll} 
& Allocation according to & \\
\cline { 2 - 3 } & Value added coef./ICOR & Wage coefficient $/ I C O R$ \\
\hline GDCF in constant prices & 4.079 & 4.109 \\
GDP in constant prices & 0.745 & 0.667 \\
Wage income in current prices & 2.073 & 2.229 \\
\hline
\end{tabular}

These figures are comparable to those in table 3 under Schemes 4 and 6, respectively. Although the figures here are higher than in table 3 , note that the directions of changes are maintained. Thus our results regarding the allocation Schemes 4 and 6 will not be affected by these alternative allocation rules. 
income. It can be inferred, therefore, that protection of wages leads to higher growth with equity. ${ }^{2}$

(2) In both the periods, total investment goes up, while the private investment falls universally. This indicates that the complementarity effect and the crowding effect coexist, although their magnitudes vary from scheme to scheme and case to case.

(3) As already pointed out, the share of wage income in disposable income increases, implying that income distribution improves with an increase in public investment.

How does the total investment go up, if private investment falls? Or, to put it the other way round, why is the ultimate fall in private investment less than the rise in public investment? The reasons are:

- Increased public investment results in cheaper capital goods. For example, price indices of construction and plant and equipment under Scheme 1 in period 1 decrease by 0.07 and 2.48 percent, respectively. The decline in the prices of capital goods induces higher private investment. Moreover, except in Case III where administered prices are increased, lower capital costs tend to reduce the (cost-based) prices of intermediate goods (e.g., the weighted average of administered prices decreases by 0.08 percent under Scheme 1 in period 1) which, in turn, encourages private investment.

- With a rise in national income, savings increase.

It may be noted that the above results hold irrespective of the mode of allocation and financing of public investment.

\subsection{Impact of various allocation rules}

As mentioned earlier, we have examined three rules for allocating public investment among nine administered goods. Since the impact of investment allocation is realised after one period, we will highlight the results in period 2 as presented in tables 2,3 and $4 .{ }^{13}$

\footnotetext{
${ }^{12}$ Throughout we will use the share of post-tax wage income in disposable income as the measure of income distribution. When tax on wage income is derived using a fixed fraction, the percentage change in post-tax and pre-tax wage income is identical. Note that the use of fixed coefficients rules out progressive taxation of wage income. Also this measure of income distribution does not take into account changes in consumer prices.

If alternatively the share of wage income in nominal GDP is chosen as a measure, income distribution worsens in most cases without wage indexation, but generally improves when wages are protected. This measure, however, is insensitive to changes in income taxes at the aggregate level (e.g., in Case II), since GDP will remain unchanged as change in tax will exactly match the change in disposable income.

${ }^{13}$ It is seen that except for imports, the macro-economic aggregates differ very little across Schemes 2, 4 and 6 . This is because of the fact that under all schemes, there is excess demand for only three goods (industrial raw materials, crude petroleum and natural gas, and other basic and intermediate goods). Since these goods account for only 18 percent of total value added in the base year, their linkage with macro-aggregates is weak.
} 
(1) The crowding out of private investment is largest under Scheme 4 and lowest under Scheme 2. Consequently, total investment follows just the reverse order.

(2) The growth of national income is highest under Scheme 4 and lowest under Scheme 6. However, the share of wages in disposable income is just the opposite. ${ }^{14}$ Thus, there seems to be a trade-off between growth and equity as far as allocation of public investment is concerned. The previous result that the total investment is higher under Scheme 6 than under Scheme 4 , however, implies that the growth of national income is likely to be higher under Scheme 6 than under Scheme 4 in the third period. Therefore, one should be careful before arriving at a firm conclusion.

Nevertheless, the fact that the national income is lower when the total investment is more under Scheme 6 as compared to Scheme 4 calls for an explanation. It can be noted (from Appendix A) that the demand for construction would go up if the share of wages in disposable income increases faster than the disposable income. In Scheme 6, therefore, the investment on construction registers an increase, and this increase more than offsets the fall, if any, in the investment on plant and equipment. The lower national income under Scheme 6 is because the sectors having higher value added are observed to have lower wage share, on the basis of which allocation of public investment is made under this scheme.

(3) The growth in the demand for imports is highest under Scheme 4, and lowest under Scheme 6. This is to be expected because, as specified in the model, the import intensity of consumption out of wage income is less than that out of non-wage income.

The above results hold irrespective of the mode of financing of public investment.

\subsection{Impact of various modes of financing}

In this section, we will analyse three modes of financing the increase in public investment specified earlier as Cases I, II and III.

Before we present the results, it is worthwhile to note that the effects of a hike in administered prices are difficult to foresee. Since not all prices in our model are cost-based, we cannot say a priori that an initial rise in

\footnotetext{
${ }^{14}$ An interesting conjecture is: What would be the results if public investment were allocated according to excess demand weighted with non-wage coefficients? We carried out two simulations where the modes of financing were, respectively, money creation (Case I) and administered prices hike (Case III). In both cases, growth was found to be better, while income distribution was worse, than the other allocation rules. The rates of growth of national income, wage income and disposable income were $0.677,2.067$ and 1.532 percent, respectively, in Case I, and $0.619,1.959$ and 1.522 percent, respectively, in Case III. Imports were found to be growing at 6.462 percent and 6.555 percent in Case I and Case III, respectively.
} 
Table 2

$10 \%$ increase in public investment financed through money creation - effect on macro-variables. ${ }^{\mathrm{a}}$

\begin{tabular}{lccc}
\hline Variable & Scheme 2 & Schene 4 & Scheme 6 \\
\hline Period I & & & \\
1. Private investment in constant prices & -3.050 & -3.350 & -3.350 \\
2. GDCF in constant prices & 3.140 & 3.140 & 3.140 \\
3. GDP in constant prices & 0.156 & 0.156 & 0.156 \\
4. General price index & 0.396 & 0.396 & 0.396 \\
5. Wage income in current prices & 0.747 & 0.747 & 0.747 \\
6. Disposable income in current prices & 0.368 & 0.368 & 0.368 \\
7. Imports & 2.103 & 2.103 & 2.103 \\
& & & \\
Period 2 & & & \\
1. Private investment in constant prices & -1.451 & -1.527 & -1.489 \\
2. GDCF in constant prices & 3.784 & 3.742 & 3.769 \\
3. GDP in constant prices & 0.631 & 0.641 & 0.551 \\
4. General price index & 1.210 & 1.221 & 1.050 \\
5. Wage income in current prices & 2.221 & 2.094 & 2.260 \\
6. Disposable income in current prices & 1.447 & 1.453 & 1.256 \\
7. Imports & 3.448 & 5.046 & 1.506 \\
\hline
\end{tabular}

${ }^{a}$ The $i j$ th element indicates the percentage change in the $i$ th variable under the $j$ th Scheme.

administered prices will result in an increase in all prices. Although there will be cost-push pressures on prices, every administered price hike will also be accompanied by income effects which will affect the demand vector in the opposite direction. If the price effect dominates, demand will decline which, in turn, will hamper growth. If, on the other hand, the income effect dominates, there will be growth [see also Chetty and Ratha (1987)].

The results as evident from tables 2,3 and 4 are as follows:

(1) Private investment declines throughout, decline being highest in Case II (where the mode of financing is direct taxation) and lowest in Case I (when the mode of financing is money creation). Correspondingly, although total investment rises in all three cases, it is lowest in Case II and highest in Case I. Low capital formation in Case II is because the richest income group (which has the highest propensity to save) will tend to pay a part of taxes by diverting its savings. Capital formation is lower in Case III than in Case I because, as the corresponding equations suggest, an increase in administered prices of basic inputs tends to reduce the supply of construction and plant and equipment.

(2) National income registers growth in both periods in Case I. It grows in both periods in Case III as well, indicating that the income effect of administered price hike is stronger than the price effect operating within the model. In Case II, national income decreases in period 1, but increases in period 2. When all three cases are compared, it is seen that the growth of national income follows the same pattern as capital formation in period 1 - 
Table 3

$10 \%$ increase in public investment financed by taxing the richest - effect on macro-variables. ${ }^{\mathrm{a}}$

\begin{tabular}{lrrr}
\hline Variable & Scheme 2 & Scheme 4 & Scheme 6 \\
\hline Period I & & & \\
1. Private investment in constant prices & -4.218 & -4.218 & -4.218 \\
2. GDCF in constant prices & 2.544 & 2.544 & 2.544 \\
3. GDP in constant prices & -0.015 & -0.015 & -0.015 \\
4. General price index & -0.215 & -0.215 & -0.215 \\
5. Wage income in current prices & 0.184 & 0.184 & 0.184 \\
6. Disposable income in current prices & -1.433 & -1.433 & -1.433 \\
7. Imports & -4.139 & -4.139 & -4.139 \\
& & & \\
Period 2 & & & \\
1. Private investment in constant prices & -2.868 & -2.940 & -2.902 \\
2. GDCF in constant prices & 3.048 & 3.008 & 3.033 \\
3. GDP in constant prices & 0.419 & 0.428 & 0.335 \\
4. General price index & 0.364 & 0.375 & 0.199 \\
5. Wage income in current prices & 1.369 & 1.249 & 1.413 \\
6. Disposable income in current prices & -0.610 & -0.603 & -0.806 \\
7. Imports & -3.693 & -2.162 & -5.714 \\
\hline
\end{tabular}

${ }^{a}$ The $i j$ th element indicates the percentage change in the $i$ th variable under the $j$ th Scheme.

Table 4

$10 \%$ increase in public investment financed by increasing the mark-up on administered prices cffect on macro-variables.

\begin{tabular}{|c|c|c|c|}
\hline Variable & Scheme 2 & Scheme 4 & Scheme 6 \\
\hline \multicolumn{4}{|l|}{ Period I } \\
\hline 1. Private investment in constant prices & -4.019 & -4.019 & -4.019 \\
\hline 2. GDCF in constant prices & 2.624 & 2.624 & 2.624 \\
\hline 3. GDP in constant prices & 0.104 & 0.104 & 0.104 \\
\hline 4. General price index & 0.712 & 0.712 & 0.712 \\
\hline 5. Wage income in current prices & 0.729 & 0.729 & 0.729 \\
\hline 6. Disposable income in current prices & 0.378 & 0.378 & 0.378 \\
\hline 7. Imports & 2.271 & 2.271 & 2.271 \\
\hline \multicolumn{4}{|l|}{ Period 2} \\
\hline 1. Private investment in constant prices & -2.323 & -2.401 & -2.369 \\
\hline 2. GDCF in constant prices & 3.295 & 3.251 & 3.276 \\
\hline 3. GDP in constant prices & 0.573 & 0.583 & 0.492 \\
\hline 4. General price index & 1.472 & 1.484 & 1.316 \\
\hline 5. Wage income in current prices & 2.155 & 2.207 & 2.195 \\
\hline 6. Disposable income in current prices & 1.438 & 1.444 & 1.248 \\
\hline 7. Imports & 3.531 & 5.138 & 1.597 \\
\hline
\end{tabular}

${ }^{\text {aThe }} i j$ th element indicates the percentage change in the $i$ th variable under the $j$ th Scheme.

it is highest in Case I and lowest in Case II. The share of wages in disposable income, however, seems to follow the reverse pattern, i.e., it is lowest in Case I and highest in Case II. To be more specific, Case I affects the poor, while 
Case III affects the rich in general and Case II affects only the richest. Thus, there seems to be a trade-off between growth and equity when the mode of financing the public investment is considered.

(3) Quite expectedly, the rate of inflation is highest in Case III, followed by Case I and Case II.

(4) For the reason noted earlier, the demand for imports is lowest in Case II. What needs to be explained is the fact that the demand for imports is higher in Case III than in the other two cases. This is surprising because the demand for intermediate goods is expected to go down as their prices rise. The explanation is twofold:

- As mentioned earlier, the income effect seems to dominate the price effect so that the demand for intermediate goods need not fall.

- A major part of the increase in total imports is due to increase in the import of agriculture-based industrial raw materials, whose prices are not raised. The import of industrial raw materials increases because of the increase in their demand from consumer non-durables and cotton textiles.

\subsection{Financing public investment through market borrowing}

For obvious reasons, if public investment is financed by mopping-up excess credit from the banking system, the effects would be more or less the same as in the case of deficit financing (ignoring interest liabilities of the public sector). But there is an important distinction between market borrowing and deficit financing as a mode of financing public investment. It may be noted from eq. (1) above that increasing reliance on deficit financing will ease credit availability unless household savings on financial assets decrease substantially. Increasing market borrowing, on the other hand, would lead to a contraction of the government budget deficit and, hence, to a reduction in the volume of credit. Moreover, that would also result in higher demand for credit. Thus, financing public investment through market borrowing may lead to a rationing of bank credit to the private sector, thus directly crowding-out private investment. This is not the case with deficit financing where crowding-out occurs more indirectly through rising prices.

This distinctive characteristic of market borrowing showed up clearly in our simulations. We found that under all investment allocation schemes, a 10 percent increase in public investment financed through market borrowing led to a situation where the demand for credit exceeded its supply. When we tried to ration the private demand for credit, we could not obtain an equilibrium (i.e., a situation when demand for credit is less than or equal to its supply, with all other markets being in equilibrium). The reason is that when the private demand for credit is rationed, the private sector investment on final goods goes down, leading to lower incomes and lower (financial) 
Table 5

$8.7 \%$ increase in public investment financed through market borrowing - effect on macro-variables. ${ }^{a}$

\begin{tabular}{|c|c|c|}
\hline \multirow[b]{2}{*}{ Variable } & \multicolumn{2}{|l|}{ Scheme 1} \\
\hline & Period 1 & Period 2 \\
\hline 1. Private investment in constant prices & -2.924 & -1.933 \\
\hline 2. GDCF in constant prices & 2.588 & 2.925 \\
\hline 3. GDP in constant prices & 0.069 & 0.333 \\
\hline 4. General price index & 0.228 & 0.708 \\
\hline 5. Wage income in current prices & 0.190 & 0.866 \\
\hline 6. Disposable income in current prices & 0.150 & 0.798 \\
\hline 7. Imports & 1.231 & 1.522 \\
\hline
\end{tabular}

${ }^{\text {a }}$ The $i j$ th element indicates the percentage change in the $i$ th variable under the $j$ th Scheme.

savings. The increase in public investment that occurs simultaneously does not counter this deflationary trend effectively enough. As a result, financial savings decrease leading to a decrease in the supply of credit. This necessitates further rationing of private demand for credit and a fresh round of effects ensues ruling out convergence to an equilibrium.

Our next exercise was to find out up to what level of public investment can be financed through market borrowing without over-constraining the credit market. It was found that under Scheme 1, an 8.7 percent increase in public investment is just the limit after which there is excess demand for credit. This limit will obviously be different under different investment allocation rules.

The results of an 8.7 percent increase in public investment under Scheme 1 financed through market borrowing are summarized in table 5 . It is evident that private investment decreases, but total investment increases in both periods. Although national income decreases initially, it increases in period 2. The share of wages in disposable income also improves in both periods.

\section{Concluding remarks}

To summarize the results of our simulations:

(1) Whenever public investment is raised, private investment decreases. In that sense, there is crowding out of private investment. The extent of crowding out varies with different modes of allocation and financing of public investment - it is the highest when the mode of financing is market borrowing.

(2) Although private investment decreases, total investment in the economy increases when public investment is stepped up. Since public investment is exogenously controlled, the increase in total investment is really due to a rise 
in private investment. In that sense, there is complementarity between public and private investment. The complementarity effect also varies with the mode of allocation and financing of public investment.

(3) Increase in public investment leads to higher national income.

(4) When wages are protected against a rise in food prices, an increase in public investment improves income distribution. This conclusion, however, is sensitive to the measure of income distribution one adopts.

Our exercises have clearly shown that stepping up of public sector investment, although it involves crowding-out of private investment, has a favourable impact on growth. When combined with wage indexation, income distribution also improves. Thus crowding-out, when considered in a wider perspective, need not be undesirable.

Before we conclude, however, we must point out two important sources of weakness of our model. We have used a highly simplified lag structure (a one-year lag between investment and accrual of output) which ought to be improved for a more realistic analysis. Also by using estimated demand functions for capital goods, we do not explicitly establish the technical relation between capital goods and other goods in the model. This weakness can be overcome by using a capital coefficients matrix, or by estimating production functions for other goods and obtaining the demand for capital goods from profit maximization conditions.

\section{Appendix A: Estimated supply and demand functions of capital goods}

Supply functions

$$
\begin{aligned}
& \log \left(S_{\mathrm{C}}\right)=1.194+1.182 \log \left(P_{\mathrm{C}}\right)+0.2262 \log (P B I)-1.0504 \log \left(P_{\mathrm{I}}\right) \\
& \begin{array}{lll}
(2.847) & (1.027) \quad(-2.295)
\end{array} \\
& \bar{R}^{2}=0.74, \quad \text { D.W. }=1.08 \\
& \log \left(S_{\mathrm{PE}}\right)=1.01+0.08 \log \left(P_{\mathrm{PE}}\right)+0.72 \log (P B I)-0.39 \log \left(P_{1}\right) \\
& \begin{array}{lll}
(0.22) \quad(8.17) \quad(-1.39)
\end{array} \\
& \bar{R}^{2}=0.98, \quad D . W .=1.17
\end{aligned}
$$

Demand functions

$$
\begin{aligned}
& \log \left(D_{\mathrm{C}}\right)=-\underset{(-5.7)}{1.98-1.26 \log \left(P_{\mathrm{C}}\right)}+\underset{(4.62)}{0.99 \log (W Y / D Y)}+\underset{(7.78)}{1.21 \log (D Y)} \\
& \bar{R}^{2}=0.96, \quad \text { D. W. }=2.53
\end{aligned}
$$




$$
\begin{aligned}
& \log \left(D_{\mathrm{PE}}\right)=-\begin{array}{c}
1.92-0.38 \log \left(P_{\mathrm{PE}}\right) \\
(-3.06)
\end{array} \\
& \bar{R}^{2}=0.98, \quad \text { D.W. }=1.12 .53 \log \left(P_{\mathrm{CNDNT}}\right)+\underset{(5.12)}{0.54 \log (P B I)}
\end{aligned}
$$

\title{
Notations
}

\author{
$\mathrm{C}=$ Construction. \\ PE $=$ Plant and equipment. \\ $P_{i} \quad=$ Price of $i$ th good, $i=\mathrm{C}, \mathrm{PE}$ (endogenous). \\ $P B I \quad=$ Public investment (exogenous). \\ $P_{1} \quad=$ Weighted average of prices of intermediate goods (endogenous). \\ $W Y \quad=$ Wage income (endogenous). \\ $D Y \quad=$ Disposable income of the household (endogenous). \\ $P_{\text {CNDNT }}=$ Price of consumer nondurables, non-textiles (endogenous). \\ The equations are estimated using time series data from 1960-61 to \\ $1980-81$. Figures in parentheses indicate $t$-values. D.W. denotes Durbin- \\ Watson statistic.
}

\section{References}

Chetty, V.K. and D.K. Ratha, 1987, Inflation, growth and public sector price policies, Discussion paper (Indian Statistical Institute, Delhi Centre, New Delhi).

Chetty, V.K., B.K. Pradhan and Atul Sarma, 1987, Money, debt and taxes: Some implications for growth and distributions, Mimeo. (Indian Statistical Institute, Delhi Centre, New Delhi).

Chetty, V.K., S. Krishna, S. Ramani and P.V. Srinivasan, 1986, Growth, equity and economic policies: Some lessons from a model of the Indian economy, Mimeo. (Indian Statistical Institute, Delhi Centre, New Delhi).

Government of India, 1956, Second five year plan, Summary (Planning Commission, New Delhi).

Government of India, 1981, Technical note to the sixth plan (Planning Commission, New Delhi).

Government of India, 1986, Administered price policy, Discussion paper (Ministry of Finance, New Delhi).

Jha, Shikha and S. Mundle, 1987, Inflationary implications of resource mobilisation through administered price increases. Economic and Political Weekly XXII, no. 33.

Krishnamurly, K., 1985, Inflation and growth: A model for India, in: K. Krishnamurty and V. Pandit, eds., Macroeconometric modelling of the Indian economy (Hindustan Publishing Corporation, New Delhi).

Murty, K.N. and R. Radhakrishna, 1981, Agricultural prices, income distribution and demand patterns in a low income country, Paper presented at the symposium on economic theory and planning, Indian Statistical Institute, Bangalore.

Pradhan, B.K., 1987, Public policies and the dynamics of development: A macroeconomic theory for developing economies, Ph.D. thesis (Indian Statistical Institute, New Delhi).

Ratha, D.K., 1987, Planning and resource mobilisation in a developing economy, Ph.D. thesis (Indian Statistical Institute, New Delhi).

Saigal, R., 1979, Efficient algorithms for computing fixed points when mappings may be separable (North Western University, Evanston, 1L).

Shoven, J. and J. Whalley, 1984, Applied general equilibrium models of taxation and international trade: An introduction and survey, The Journal of Economic Literature 22.

Sundararajan, V. and S. Thakur, 1980, Public investment, crowding out and growth: A dynamic model applied to India and Korea, Staff papers (International Monetary Fund, Washington, DC).

World Bank, 1979, State intervention in the industrialization of developing countries: Selected issues, Staff working paper no. 341 (World Bank, Washington, DC). 